\title{
Navigating Virtual Turbulence During The Pandemic: Reflections And Lessons
}

\author{
Bernard L. Dillard \\ Assoc. Prof, Department of Science and Mathematics, Fashion Institute of Technology \\ bernard_dillard@fitnyc.edu \\ DOI: 10.29322/IJSRP.11.10.2021.p11819 \\ http://dx.doi.org/10.29322/IJSRP.11.10.2021.p11819
}

\begin{abstract}
Pandemic woes did — and are still doing — their fair share at upending the status quo in America and abroad. From March 2020 until now, their implications surely have been impactful, especially within the realm of educational leadership. Mayors, superintendents, and other school administrators have had to toe the line by devising strategies to ensure student success when virtual learning became the only option. Leaders faced the struggle of preparing teachers, faculty, and even some students to engage in online instruction, even though many of them had no such prior experience. Of note during this time was how leaders at Fashion Institute of Technology (FIT), one of the colleges in the State University of New York (SUNY) system, adapted to this new academic normal, despite glaring uncertainties. Investigating these related challenges against the backdrop of turbulence theory provides invaluable insight for those whose responsibility it was and is to lead in educational spaces during perilous times. More specifically, marrying the basic tenets of turbulence theory with the overarching principles guiding the four ethical paradigms helped to make the obligatory transition from face-to-face instruction to remote learning less ominous. We seek to support such a claim herein and pause to reflect on lessons learned along the way.
\end{abstract}

Key Terms: Covid-19, turbulence theory, ethical paradigms, virtual learning, remote learning, school reform, distrust

\section{INTRODUCTION}

As I sat at the beach at Coney Island and grabbed the sand with my toes, I tried to convince myself that the summer would have some sense of normalcy to it, given the whirlwind of events that had occurred since mid-March. The email that I had been waiting for was finally in my inbox, and I dreaded reading it. It was from the president of my college:

July 8, 7:05PM

Subject: Fall Reopening Plan

Dear Community,

You will hear me repeat this throughout the summer and indeed until classes resume.

I realize that this is frustrating and even tiresome to hear, especially after so many months of isolation and sacrifice. But this is our reality - a reality which you have endured since last semester with grace and resilience. I know it has been difficult and I am grateful for your patience and perseverance. The plan itself, whose details will be reviewed and refined by deans, chairs, and college-wide advisory groups, provides the 
As one might expect, my beachfront bliss and relaxation gave way to concern and a bit of angst, not knowing how the academic needs of students would be effectively met in the coming fall term. While many grappled with how to address such a tentative situation within the public and private school sectors, Covid challenges were just as prominent among leaders at the university level. As a faculty member at FIT, I was caught in the middle of meeting demands from campus leadership—which had its own demands to meet from the SUNY system - and delivering quality instruction to students via a platform many of us had never used before: virtual learning. It was this reality that provided the most chaos and institutional turbulence that would have to be mitigated.

\section{TURBULENCE DEFINED}

Having obvious roots in the world of aircraft flights, turbulence theory as an academic idea may be applied to any field and any organization. Stemming from Steven Gross' unsettling experience on a flight, the theory as applied to educational circles serves as a metaphor, describing how leadership calibrates the severity of challenging issues and how it contextualizes a problem as strategies are explored to move to less chaotic waters (Shapiro et al., 2008). The theory, when viewed in light of threat levels to the organization, can help guide decision-making measures to increase probabilities of a "smooth landing." In the current case of providing adequate virtual instruction during the pandemic, factors contributing to the chaos were and are tremendously complex. In particular, city leaders, educators, administrators, and students alike scrambled to keep pace with the academic demands amid such a bumpy transition into virtual spaces. On the continuum of the varying strata of turbulence classification, one may easily make the case for dubbing the transition to virtual learning on the college campus during the pandemic as severe, one step shy of extreme, the most drastic level; at severe, the whole operational flow seems at risk, and problems are so dire that normal administrative actions seem insufficient (Shapiro \& Gross, 2013). The decision to close all public and private schools in Kenya and require that all students repeat the grade would indeed qualify for the extreme designation on the turbulence spectrum, as leaders felt its ability to meet the needs of students was not sufficient given teacher preparation levels (Dahir, 2020).

\section{Positionality}

Of particular note within the turbulence theory framework is that of positionality, especially in this instance of virtual pandemic learning. Positionality refers to the notion that stakeholders and students may have varying responses to the unrest based on how close they feel to it (Grooms, 2019). This is an integral component in the navigation of chaos because administrators need to know how to prioritize in order to minimize the effects of the unrest across various groups. In the case of virtual pandemic learning, the president and other campus leaders had to be cognizant of how various constituents would react to the suspension of classes and full transition to virtual learning. Though all students would feel some degree of discomfort, first-time freshmen would 
probably be affected the most since they would have to stay home and juggle college-level courses with no on-campus interaction.

In addition, students who are disabled would face a number of challenges, depending on the type of disability (e.g., the Deaf community). Most instructors would feel the virtual heat, but those who never taught virtually before (and vowed that they never would!) would probably experience a great deal of angst. Campus leadership, then, should be well aware of how turbulence would affect different constituents differently at my college and be prepared to act accordingly.

Stability

Administrators further had to consider how the notion of stability contributed to maintaining manageable turbulence levels. Strictly, stability refers to how unchanging or firm something is or how equilibrium is preserved. With respect to virtual learning, it became vitally important to consider factors that would threaten such a notion. For example, how would administrators address the reality that not all students would have access to consistent internet service or one with enough Broadband to support video cameras and downloads. The same would hold true for instructors—especially adjunct instructors, who may not be able to afford such speedy internet services either. Too, because of Covid, students' home life may be shaky, in that they may have to care for siblings (or even parents) during instructional time. How do instructors take this instability into account since students are not on campus to focus in a normal classroom? This also would hold true for instructors, even those who are tenured and ranked. If they have children and no childcare services are available, this may threaten the sense of stability and affect the quality of instruction being delivered.

Cascading

Referencing the downward flow of running water, the notion of cascading takes into account the fact that "challenges rarely occur in isolation but are dynamic, resulting from interacting forces and events" (Conrad \& Klomes, 2021, p. 108). These changing forces often require administrators to aim at moving targets that make turbulence more elusive and problematic. Administrators had to consider various situations that morphed and changed as days progressed during virtual learning during the pandemic. Regulations from SUNY had to be updated regularly as the Center for Disease Control updated its advice concerning staying ahead of the curve on virus safety measures. This could affect students' and instructors' sense of well-being, not knowing when the mandatory virtual experience would come to an end. In addition, students, instructors, and their families may have contracted the virus at any point during the semester, which could cause changes in how instruction is delivered or received. Further, if a student has to eventually get a job to support the family during Covid, this adds to the stress that students must contend with and can affect virtual performance.

\section{VIRTUAL LEARNING VIS-À-VIS THE FOUR ETHICAL PARADIGMS}

\section{The Ethic of Care}

Arguably, remote learning in and of itself warrants a certain level of compassion on the part of instructors, but virtual learning during the pandemic was relentlessly brutal. Unlike online classes, which are typically asynchronous, virtual classes tend This publication is licensed under Creative Commons Attribution CC BY. 
to occur in real time. Administrators reminded faculty that international students comprised about $11.9 \%$ the student population.

Some come from as far as South Korea. Consequently, this meant attending class during real time could mean they could be attending during the wee hours of the morning. Although classes were still conducted during the regular eastern standard time, those overseas could watch the recorded lecture and turn in any assignments within 24 hours of the live class. With respect to grading, instructors would perhaps consider only using some of the assignments in a category toward the grade (e.g., use only 3 out of 4 quizzes). This keeps the standard for the class at a high level but allows for students to navigate through turbulence they may be feeling at any point during the class. Since students may have had to learn various course meeting platforms (Blackboard, Zoom, Webex), instructors remained somewhat lenient in participation grades to account for students' learning curve. In all, helping students understand that they are being considered with concern would help to get them make it through.

\section{The Ethic of Justice}

Viewing the virtual experience during the pandemic through this lens is much tougher. Administrators kept tuition and fees relatively intact for students during the semester. The university, at the end of the day, still had expenses that confronted it, and students had to still pay for tuition, even though they may not have had access to certain services. To stay afloat as well, administrators required all instructors to become proficient with the intricacies of conducting class virtually. There was no room for negotiation. Whether they were veterans at teaching remotely or mere amateurs, the administration allowed for no excuses when it came to preparing for instruction in that regard, even though instructors only had one solid week to make the transition. Further, students were required to keep up with all coursework, independent of shoddy internet service. Though provisions were put in place to assist with difficulties that students may have experienced, they would still have to find a way to negotiate it eventually and do the work.

\section{The Ethic of Critique}

It became quickly apparent that administrators had to consider addressing inequities that revealed themselves during this most unsettling time, which allowed them to invoke basic tenets of the ethic of critique (Shapiro \& Stefkovich, 2016). This one best guides my thinking because it gets at leveling the playing field for all students as it relates to grading during such an unsettling time. As such, administrators questioned the impact of grading to reduce turbulence that students experienced in that regard. As a result, students were able to self-select grades at the end of the semester that they wanted to change to "Satisfactory" (S) instead of keeping the grade that was earned. This excluded courses in capstone courses or those which may would impact their financial status at the college. This administrative decision was major, as it allowed the bar of the class to remain high but allowed rigid policies to be questioned and adjusted, given the critical circumstances. Also, how would instructors change their policies to mitigate cheating in virtual spaces? Many instructors had to change how they evaluated students' knowledge in some cases. Cheating would become more of a reality with students, as they could communicate with fellow students during assignments (i.e., take pictures of assignments and text to friends). As a result, some instructors changed the format of quizzes and exams (which they would not have ordinarily done) to account for such a reality. 
How would administrators deal with varying expectations within the community concerning what would be best for students, faculty, and staff? Through a series of emails, leaders would keep all members of the community abreast of decisions pondered and made every step of the way. In addition, administrators conducted a series of virtual town hall meetings, in which those in attendance would have the opportunity to engage with campus leadership and ask questions civilly through online chat about difficulties they faced about the virtual experience during the pandemic. Department and division representatives also met as units to discuss the same. Union representation joined in on meetings so that its voice would be able to be heard on behalf of fulltime as well as part-time faculty. Having these periodic meetings helped the administration keep its finger on the pulse of the brewing problems all in an effort to keep the best interest of the students at the forefront.

\section{A HISTORY OF SCHOOL REFORM AND DISTRUST}

Although some form of distance learning can be dated by to the mid-19th century with the post office serving as the medium of education, significant inroads into provided such learning were gained via the use of television. In 1933, the Daily Iowan announced that the University of Iowa would offer television courses in the upcoming fall semester, a first offering of any college department in America (McKune, 1966). After such ground-breaking advances in this type of instructional mode, conventional schools, universities, and colleges began to adopt similar means of teaching outside of the traditional classroom, offering services from kindergarten through graduate school (1966).

Nestled between course offerings via television and computer platforms using internet is the notion that America's schools were failing and needed some sense of rebooting. The Sputnik launch, which placed Russia ahead of all other countries in the race to space, provided the much-needed catalyst to awaken America's sense of competitiveness on the global stage (Law, 2009). This aspect of reform strengthened technology's role in revolutionizing America's educational landscape, including a new method of content delivery. The country in this respect was getting its footing back and was on Russia's heels in becoming the world's leader on the educational front.

The advent of the computer and invention of the World Wide Web made distance learning even more of an attraction in leveling the educational playing field and making content acquisition less of a challenge. With the University of Phoenix and Jones International Universities leading the way in the late twentieth century by offering postsecondary degrees and becoming the first fully accredited web-based university, respectively, other universities followed suit and made distance learning a priority in their educational mission (Casey, 2008). Tremendous strides have been made in the world of digital learning since then, with colleges and universities making valiant efforts to make learning accessible to students, especially those in underserved communities. As of fall 2020, data reveals that there were approximately 8.4 million students enrolled in a bachelor's degree-seeking program, about 100,000 students shy of numbers from the year before (Hanson, 2021). Needless to say, distance and remote learning has contributed significantly to education reform and its place in the fabric of America. 
During the 1918 (Spanish) flu, schools most schools shut down for weeks to four months; New York City, New Haven, and Chicago were the only three major cities that kept their schools open during this time without any time of closure (Markel, 2020). While students remained at home, very little education-related work was completed; though teachers would send work home, students generally got jobs and worked until school restarted. Schools that remained open in the three cities mainly did so on the advice of health officials, who remained convinced that schools were generally better sanitized and cleaner than students' homes (2020)

When the H1N1 (swine) flu of 2009 reared its ugly head, roughly 700 schools closed initially to proactively guard against threats posed by the virus. After the Center for Disease Controls advised that schools should remain open and address individual cases of student or teacher infections, federal officials left decisions regarding closures up to states and local leaders; after the initial panic, schools began reopening, with serious cases having schools closed for no more than fourteen days (McKenna, 2009). Fourteen days was the longest any schools were to remain closed, and some semblance of a home-schooling plan had to be on hand in case worst fears became reality (2009). Fortunately, colleges did not close because administrators showed little to no forethought with regard to navigating the turbulence of forging ahead with coursework if situations exacerbated. Out of 50 leading higher education institutions, only one made any mention on its website of employing online learning as a way to mitigate the deleterious effects of the swine flu on its students' educational advancement (Meyer \& Wilson, 2011).

Naturally, parents are concerned whenever talk of school closures abound. Extended closures affect parents' work schedules, daycare plans, and ultimately their income. In Milwaukee, leaders' wishy-washiness with sticking with their guns related to closures related to the swine flu caused parents to balk. Officials tried out different closure strategies because of the virus, shifting agreed-upon mitigation plans several times in a short period (Navarro, Kohl, Cetron, \& Markel, 2016). This lack of consistent commitment on the part of leaders did much to fuel a sense of distrust among parents and school systems. Even in the midst of catastrophic times involving health crises, parents still expected officials to keep them in the loop of all things related to school closures. Parents' sense of confidence and trust appeared to diminish when officials made it difficult for parents to keep adjusting to new norms within short periods of time. One learns that communication is key even in the most turbulent of educational situations.

\section{A NECESSARY COURSE OF ACTION}

Considering the impact of educational reform and a review of the multiple ethical paradigms, I would have handled some of the situations similarly and some differently if I were an administrator. I am a staunch supporter of allowing students to change some of their course grades (within university guidelines) to "Satisfactory" during pandemic semesters. As they may not change failed grades to such, it keeps the standard of the course at a high level but allows for flexibility during such an unstable time.

Further, the president was wise to institute periodic town hall meetings to keep faculty, staff, and students abreast of the latest goings-on with the college's plans amid pandemic months. Although many of the items of discussions were controversial, the 
lines of communication were key to ensuring stakeholders remained apprised of policies that affected them. It was vital that campus leaders had separate town halls with students and parents in light of circumstances as well.

Though it may have seemed unfair and harsh, I stand by the decision on behalf of the administrators to require all full- and part-time faculty become skilled in teaching remotely. This is done to keep the best interest of the student in mind. Students paid for a quality education and should receive such, even in perilous times. From this perspective, this ensures that students do not lag behind and are able to stay on the road toward finishing the degree in a timely fashion.

It was imperative for university officials to consider the pandemic seriously and take steps accordingly to mitigate adverse effects associated with the virus and its challenges. In the case of my college's response overall, a "coordinated set of strategies [was] very likely needed while business-as-usual thinking need[ed] to be suspended" (Gross \& Shapiro, 2004). The only constructive turbulence needed, outside of that which already precipitated the dilemma, was mandating that faculty be trained for remote learning. Despite the fact that some full- and part-time faculty never may had taught in this fashion before, they had to address their apprehension regarding such, bite the bullet, and make education happen.

\section{LESSONS LEARNED}

One primary take-away is that one should always stay ready as an administrator or school leader. The only real turbulence is the turbulence that comes from not preparing for turbulence. One can safely assume — at any level in an organization- that turbulence is sure to occur. Failure to acknowledge such as a leader is unfortunate and is a clear sign of administrative myopia. Further, even though leaders may have plans for turbulence mapped out in general, they should learn how to master the art of adjusting. In keeping with the metaphor of turbulence in flight, pilots or sailors become adept over time at mastering the art of making midcourse corrections as they make their way to a desired end. Implied in the term is a "need for exquisite awareness of your current location, your strengths, vulnerabilities and foibles, and an ability to collect and digest a wide array of information" (Kalet, 2014). All school leaders should hope to become one of those who "fly their planes" or "steer their ships" in such a fashion, so as to minimize harm, proactively lead, and lessen the effects of the turbulence that will inevitably arise.

Until then, grabbing the Coney Island sand with my toes will be the only extent of turbulence that I hope to experience for the rest of this and the next few summers. 


\section{REFERENCES}

Casey, D. M. (2008). The historical development of distance education through technology. TechTrends, 52(2), 45-51.

Conrad, D. L., \& Klomes, J. (2021). Reform Under Turbulence: Leveraging Accreditation to Improve Principal Preparation Programs. International Journal of Educational Leadership Preparation, 106-121.

Dahir, A. L. (2020). Kenya's unusual solution to the school problem: Cancel the year and start over. New York Times.

Grooms, A. (2019). Turbulence in St. Louis County: School Transfers, Opportunity Hoarding, and the Legacy of Brown. Peabody Journal of Education, 94(4), 403-419.

Gross, S. J., \& Shapiro, J. P. (2004). Using Multiple Ethical Paradigms and Turbulence Theory in Response to Administrative Dilemmas. International Studies in Educational Administration, 32(2).

Hanson, M. (2021). Online Education Statistics. EducationData. https://educationdata.org/online-education-statistics

Kalet, A. (2014). Remediation in medical education: A mid-course correction. New York, NY: Springer. 
Law, N. (2009). Technology-supported pedagogical innovations: The challenge of sustainability and transferability in the information age. In Reforming learning (pp. 319-343). Springer, Dordrecht.

Markel, H. (2020). Analysis: Why some schools stayed open during the 1918 flu pandemic. PBS: Public Broadcasting Service. https://www.pbs.org/newshour/health/analysis-why-some-schools-stayed-open-during-the-1918-flu-pandemic

McKenna, M. (2009). CDC advises against closing schools during H1N1 outbreaks. Center for Infectious Disease Research and Policy. https://www.cidrap.umn.edu/news-perspective/2009/08/cdc-advises-against-closing-schools-during-h1n1-outbreaks

McKune, L. E. (1966). The growth of televised education. Educational Technology, 6(13), 14-16.

Navarro, J. A., Kohl, K. S., Cetron, M. S., \& Markel, H. (2016). A tale of many cities: a contemporary historical study of the implementation of school closures during the 2009 pA (H1N1) influenza pandemic. Journal of health politics, policy and law, 41(3), 393-421.

Shapiro, J. P., \& Gross, S. J. (2013). Ethical educational leadership in turbulent times:(Re) solving moral dilemmas. Routledge.

Shapiro, J. P., Gross, S. J., \& Shapiro, S. H. (2008). Ethical decisions in turbulent times. School Administrator, $65(5), 18$.

Shapiro, J. P., \& Stefkovich, J. A. (2016). Ethical leadership and decision making in education: Applying theoretical perspectives to complex dilemmas. Routledge. 